\title{
Nitrile hydratase of Rhodococcus erythropolis: characterization of the enzyme and the use of whole cells for biotransformation of nitriles
}

\author{
Ashwini L. Kamble $\cdot$ Linga Banoth • \\ Vachan Singh Meena $\cdot$ Amit Singh . \\ Yusuf Chisti · U. C. Banerjee
}

Received: 26 October 2012/ Accepted: 28 November 2012/Published online: 16 December 2012

(C) The Author(s) 2012. This article is published with open access at Springerlink.com

\begin{abstract}
The intracellular cobalt-type nitrile hydratase was purified from the bacterium Rhodococcus erythropolis. The pure enzyme consisted of two subunits of 29 and $30 \mathrm{kDa}$. The molecular weight of the native enzyme was estimated to be $65 \mathrm{kDa}$. At $25^{\circ} \mathrm{C}$ the enzyme had a half-life of $25 \mathrm{~h}$. The Michaelis-Menten constants $K_{\mathrm{m}}$ and $v_{\max }$ for the enzyme were $0.624 \mathrm{mM}$ and $5.12 \mu \mathrm{mol} / \mathrm{min} / \mathrm{mg}$, respectively, using 3-cyanopyridine as the substrate. The enzyme-containing freely-suspended bacterial cells and the cells immobilized within alginate beads were evaluated for converting the various nitriles to amides. In a packed bed reactor, alginate beads ( $2 \%$ alginate; $3 \mathrm{~mm}$ bead diameter) containing $200 \mathrm{mg} / \mathrm{mL}$ of cells, achieved a conversion of $>90 \%$ for benzonitrile and 4-cyanopyridine in $38 \mathrm{~h}\left(25^{\circ} \mathrm{C}\right.$, $\mathrm{pH}$ 7.0) at a feed substrate concentration of $100 \mathrm{mM}$. The beads could be reused for up to six reaction cycles.
\end{abstract}

Keywords Nitrile hydratase $\cdot$ Rhodococcus erythropolis . Biotransformations · Nitriles · Amides

\section{Introduction}

Nitrile hydratases (EC 4.2.1.84) are metaloenzymes that contain either non-heme iron(III) or non-corrinoid

\footnotetext{
A. L. Kamble · L. Banoth · V. S. Meena · A. Singh ·

U. C. Banerjee $(\square)$

Department of Pharmaceutical Technology (Biotechnology), National Institute of Pharmaceutical Education and Research, Sector-67, S.A.S. Nagar, Mohali 160062, Punjab, India e-mail: ucbanerjee@niper.ac.in

Y. Chisti

School of Engineering, Massey University, Private Bag 11 222, Palmerston North, New Zealand
}

cobalt(III) at the active site (Sugiura et al. 1987; Payne et al. 1997; Yamada et al. 2001; Mascharak 2002). A nitrile hydratase is composed of two subunits, $\alpha$ and $\beta$ that differ in the amino acid sequence (Mascharak 2002). These enzymes catalyze the hydration of nitriles to amides (Payne et al. 1997; Mylerova and Martinkova 2003). This reaction is of interest in various synthetic and bioremediation applications (Mylerova and Martinkova 2003; Sachi and Lindsay 2007). Nitrile hydratase from Rhodococcus rhodochrous is used for the industrial production of acrylamide from acrylonitrile (Kobayashi and Shimizu 2000; Raj et al. 2006). Similarly, a process for the degradation of acetonitrile in wastewater has been described (Hjort et al. 1990). This process uses the nitrile hydratase producing bacterium Rhodococcus pyridinivorans (Hjort et al. 1990). Nitrile hydratase has other potential applications, (Mylerova and Martinkova 2003) as various amides are used as pharmaceuticals and agrochemicals. For example, nicotinamide is used as a vitamin B3 (Lin et al. 2001) and pyrazinamide and isoniazid (isonicotinic acid hydrazide) are used as tuberculosis drugs (Ray et al. 2004). Herbicides, such as diflubenzuron, are synthesized from amides (Clifford et al. 1993). In addition, the intracellular nitrile hydratase of Rhodococcus erythropolis MTCC 1526 is purified and characterized for possible use as a soluble biocatalyst. Nitrile hydratases from Pseudomonas chlororaphis B23 (Nagasawa et al. 1987), Brevibacterium R312 (Nagasawa et al. 1986), Rhodococcus sp. RHA1 (Sachi and Lindsay 2007) and $R$. rhodochrous PA-34 (Prasad et al. 2009) have been previously characterized.

Nitrile hydratase-mediated hydrolysis of nitriles for the production of high value amides or acids can potentially displace chemical processes with environment-friendly low-temperature processes that operate at near physiological pH (Brady et al. 2004; Cantarella et al. 2006). In view 
of their high selectivity and specificity, the enzyme-catalyzed bioconversions occur with few or no side reactions. If used in an immobilized form, enzymes and cells can be reused repeatedly as biocatalysts (Nigam et al. 2009).

This work is focused on the use of nitrile hydratase containing whole cells of the R. erythropolis MTCC 1526 as an immobilized biocatalyst for the transformation of various nitriles (3-cyanopyridine, 4-cyanopyridine, benzonitrile, pyrazinonitrile, isobutyronitrile) to amides.

\section{Materials and methods}

Chemicals

Standard nitriles, amides, tetramethylethylenediamine (TEMED), ammonium persulfate, acrylamide and bisacrylamide were purchased from Sigma-Aldrich (Germany). Growth media components were purchased from Hi-Media Inc. (Mumbai, India). Matrices for protein purification were sourced from Amersham Biosciences $A B$ (Uppsala, Sweden). Solvents for HPLC were procured from Mallinckrodt Baker Inc. (Phillipsburg, USA) and Ranbaxy Chemicals Co. (Mohali, India). All chemicals and reagents were of analytical grade.

Microorganism and culture conditions

Rhodococcus erythropolis MTCC 1526 (procured from Microbial Type Culture Collection, Institute of Microbial Technology, Chandigarh, India) was maintained on a nutrient agar medium ( $\mathrm{pH}$ 7.0) as described by Tanaka and Kimura (1972). Seed culture was prepared by inoculating a single colony of the bacterium in $20 \mathrm{~mL}$ of a nutrient medium contained in a $100 \mathrm{~mL}$ Erlenmeyer flask. The nutrient medium was prepared by dissolving the following components in deionized water $(\mathrm{g} / \mathrm{L})$ : peptone 5 , beef extract 1.5 , yeast extract 1.5 and $\mathrm{NaCl} 5$. The seed culture was incubated at $25{ }^{\circ} \mathrm{C}$ for $24 \mathrm{~h}$ on a rotary shaker at $200 \mathrm{rpm}$. The inoculum was transferred to $500 \mathrm{~mL}$ Erlenmeyer flask containing $100 \mathrm{~mL}$ of the production medium (initial $\mathrm{pH}$ 8.0) and grown for $60 \mathrm{~h}$ at $25^{\circ} \mathrm{C}$. The production medium contained the following in deionized water $(\mathrm{g} / \mathrm{L})$ : peptone 5 , beef extract 1.5 , yeast extract 1.5 , $\mathrm{NaCl} 5, \mathrm{KH}_{2} \mathrm{PO}_{4} 0.5, \mathrm{~K}_{2} \mathrm{HPO}_{4} 0.5, \mathrm{MgSO}_{4} 0.5$, glycerol 10 and $\mathrm{CoCl}_{2} 0.01$.

Nitrile hydratase activity assay

Nitrile hydratase activity was measured using a modification of the method of Nagasawa et al. (1986). Thus, $100 \mathrm{mg} / \mathrm{mL}$ of cell mass (wet weight), or the cell-free culture supernatant, was mixed with phosphate buffer
(10 mM, pH 7.0) containing $400 \mu \mathrm{L}$ of $5 \mathrm{mM}$ nitriles. The reaction was allowed to proceed for $60 \mathrm{~min}$ at $20^{\circ} \mathrm{C}$ for whole cells, or for $30 \mathrm{~min}$ in the case of the cell-free extract. The reaction flask was continuously mixed at $160 \mathrm{rpm}$. The reaction was stopped by adding $0.2 \mathrm{~mL}$ of $1 \mathrm{M} \mathrm{HCl}$. Cells were removed by centrifugation at $13,000 \mathrm{~g}$ for $10 \mathrm{~min}$. The amount of nicotinamide formed in the reaction mixture was determined by HPLC.

Analytical methods

\section{Reversed phase HPLC}

The different nitriles and amides were detected by high performance liquid chromatography (Shimadzu 10AD VP, Kyoto, Japan) using a reversed phase column $(4.6 \times 250 \mathrm{~mm}$; Phenomenex, USA). For the detection of benzonitrile, benzamide, isobutyronitrile, isobutyramide, pyrazinecarbonitrile and pyrazinecarboxamide, a mobile phase consisting of acetonitrile:water $65: 35 \mathrm{v} / \mathrm{v}$ with a flow rate of $0.5 \mathrm{~mL} / \mathrm{min}$ was used. Aromatic nitriles and the corresponding amides were detected at $254 \mathrm{~nm}$ while the aliphatic nitriles and their corresponding amides were detected at $210 \mathrm{~nm}$. In the case of 3-cyanopyridine, nicotinamide, 4-cyanopyridine and isonicotinamide, the mobile phase consisted of phosphate buffer $(50 \mathrm{mM}, \mathrm{pH} 7.0)$ and acetonitrile mixed in the proportion of $95: 5$ by volume. The flow rate was $1 \mathrm{~mL} / \mathrm{min}$ and detection was at $230 \mathrm{~nm}$.

\section{Protein content}

Protein concentration in the various samples was estimated by Bradford's dye binding assay using bovine serum albumin as the standard (Bradford 1976). Absorbance was monitored at $595 \mathrm{~nm}$ in a microplate scanning spectrophotometer (E max, Molecular Devices, Precision Microplate Reader, USA).

\section{Enzyme purification}

Protein purification was performed using a fast performance liquid chromatography (FPLC) system (Akta Prime, Amersham Pharmacia Biotech, Uppsala, Sweden). All process was carried out at $4{ }^{\circ} \mathrm{C}$ in buffer A $(50 \mathrm{mM}$ phosphate buffer, $\mathrm{pH} 6.8$, containing $20 \mathrm{mM}$ sodium butyrate). The nitrile hydratase activity in various fractions was determined using the earlier specified method.

\section{Preparation of cell-free extract}

Rhodococcus erythropolis cells were harvested by centrifugation $(7,000 \mathrm{~g}, 15 \mathrm{~min})$ and washed with the earlier specified buffer A. The washed cell mass was suspended in 
$200 \mathrm{~mL}$ of buffer A and then disrupted by ultrasonication for $20 \mathrm{~min}$ at $4{ }^{\circ} \mathrm{C}$. The cell debris was removed by centrifugation $\left(30,000 \mathrm{~g}, 30 \mathrm{~min}, 4^{\circ} \mathrm{C}\right)$. The clear supernatant thus obtained was used as the cell-free extract in further work.

\section{Ammonium sulfate precipitation}

Proteins were precipitated by adding ammonium sulfate to the cell-free extract to a level of $30 \%$ of saturation. The mixture was stirred on ice for $1 \mathrm{~h}$. The precipitate formed was removed by centrifugation $\left(30,000 \mathrm{~g}, 30 \mathrm{~min}, 4{ }^{\circ} \mathrm{C}\right)$ and discarded. The clear supernatant obtained was subjected to a further ammonium sulfate precipitation at $60 \%$ of the saturation concentration. The mixture was stirred as before. The precipitate was collected by centrifugation $\left(30,000 \mathrm{~g}, 30 \mathrm{~min}, 4{ }^{\circ} \mathrm{C}\right)$ and dissolved in buffer A. This solution was dialyzed against the same buffer to remove ammonium sulfate.

\section{Anion exchange chromatography}

The dialyzed solution was applied to a Q-Sepharose column $(1.6 \times 10 \mathrm{~cm})$ pre-equilibrated with buffer $\mathrm{A}$ at a flow rate of $1 \mathrm{~mL} / \mathrm{min}$. The enzyme was eluted by $\mathrm{NaCl}$ $(0-1 \mathrm{M})$ in buffer $\mathrm{A}$. The active fractions were eluted at $350 \mathrm{mM} \mathrm{NaCl}$ concentration. These were pooled and then concentrated with a Centricon YM 10 ultrafiltration membrane (Millipore, Bedford, USA).

\section{Hydrophobic interaction chromatography}

The concentrated fraction from the previous step was subjected to hydrophobic interaction chromatography. Thus, the concentrated fraction was applied to a phenylSepharose column $(1.6 \times 15 \mathrm{~cm})$ (Amersham Biosciences, Uppsala, Sweden), pre-equilibrated with $1 \mathrm{M}$ ammonium sulfate in phosphate buffer $(50 \mathrm{mM}, \mathrm{pH} 7.0)$ and eluted at a flow rate of $1 \mathrm{~mL} / \mathrm{min}$ using a 1-0 $\mathrm{M}$ linear gradient of ammonium sulfate in buffer A. Nitrile hydratase was eluted at $560-450 \mathrm{mM}$ ammonium sulfate concentration.

\section{Estimation of the molecular weight of the purified native nitrile hydratase}

The molecular weight of the native enzyme was determined using Sephacryl S-200 gel permeation column $(700 \times 15 \mathrm{~mm}, 47 \mu \mathrm{m})$ (Amersham Biosciences, Uppsala, Sweden). The column was eluted with phosphate buffer $(50 \mathrm{mM}, \mathrm{pH} 6.8)$ containing $20 \mathrm{mM}$ sodium $n$-butyrate. The mobile phase flow rate was $0.5 \mathrm{~mL} / \mathrm{min}$. The column was calibrated with the following standard proteins: thyroglobulin $(663 \mathrm{kDa})$, apoferritin $(443 \mathrm{kDa})$, alcohol dehydrogenase (150 kDa), bovine serum albumin (66 kDa) and carbonic anhydrase $(29 \mathrm{kDa})$.

Sodium dodecyl sulfate-polyacrylamide gel electrophoresis (SDS-PAGE)

Denaturing polyacrylamide gel electrophoresis was performed on purified nitrile hydratase using the method described by Laemmeli (1970). A $12 \%$ SDS-PAGE gel was used with tris-glycine buffer system. Gels were developed using a Hoefer miniVE vertical gel electrophoresis system (Amersham Biosciences, Uppsala, Sweden) equipped with a EPS-301 constant power supply. The protein bands were visualized by silver staining (Dráber 1991). The molecular weights of the purified nitrile hydratase subunits (denaturing gel) were estimated by comparison with the migration bands of the standard proteins (Amersham Biosciences, Uppsala, Sweden).

Characterization of the purified nitrile hydratase

The activity profiles of the purified nitrile hydratase were characterized at various $\mathrm{pH}$ and temperature values. The pH stability and thermostability of nitrile hydratase were also determined. The effect of various metal ions and inhibitors on the activity of the enzyme was examined. Substrate specificity was checked using various nitriles. The Michaelis-Menten kinetic parameters $K_{\mathrm{m}}$ and $v_{\max }$ were estimated using the Lineweaver-Burk plot method.

Immobilization of whole cells in alginate

The bacterial cells were recovered from the culture broth by centrifugation $(7,000 \mathrm{~g}, 15 \mathrm{~min})$, washed with phosphate buffer $(10 \mathrm{mM}, \mathrm{pH} 7.0)$ and recovered $(10,000 \mathrm{~g}, 10 \mathrm{~min})$. The washed cells were resuspended in $10 \mathrm{~mL}$ of Tris- $\mathrm{HCl}$ buffer $(20 \mathrm{mM}, \mathrm{pH} 7.0)$ to achieve a cell concentration of $200 \mathrm{mg} / \mathrm{mL}$. Prior to mixing with the cells, various amounts of sodium alginate had been dissolved in the Tris$\mathrm{HCl}$ buffer $(20 \mathrm{mM}, \mathrm{pH} 7.0)$ solution by heating in a microwave oven. This solution was cooled to room temperature and then mixed with the cells. The alginate beads were formed by dripping the resulting cell slurry through a syringe, into a chilled solution of calcium chloride $(0.2 \mathrm{mM})$. The beads were hardened by refrigeration $\left(4{ }^{\circ} \mathrm{C}\right)$ for $30 \mathrm{~min}$ and then washed with $0.9 \% \mathrm{NaCl}$.

Optimization of reaction conditions using immobilized cells

The effect of alginate beads prepared with different concentrations of sodium alginate $(1.0-2.5 \%, \mathrm{w} / \mathrm{v})$ and bead size were assessed for nitrile conversion. The bead size was 
controlled by using syringes with different orifice sizes (1-5 mm). The optimal buffer strength for the reaction was identified by carrying out the reaction at various concentrations $(20,50,100,150$ and $200 \mathrm{mM})$ of Tris- $\mathrm{HCl}$ buffer $(\mathrm{pH}$ 7.0). The effect of different substrate concentrations $(50-100 \mathrm{mM})$ on the conversion of 3-cyanopyridine was examined using alginate immobilized cells. The effect of varying cell concentrations $(200,250,300,350,400$ and $450 \mathrm{mg} / \mathrm{mL}$ ) in the immobilized matrix were also observed. The stability and reusability of the alginate beads were improved by strengthening them through a cross linking treatment. For this, after the beads were prepared as previously explained, they were suspended for $1 \mathrm{~h}$ in a solution of glutaraldehyde $(0.2 \mathrm{M})$ and polyethyleneimine $(0.5 \%)$. Afterwards, the beads were washed thoroughly with deionized water and used for the biotransformation reaction. Samples were collected at regular intervals and analyzed using HPLC.

\section{Results and discussion}

\section{Enzyme purification}

The purification of nitrile hydratase has been reported from certain bacteria (Hjort et al. 1990; Prepechalová et al. 2001). The intracellular nitrile hydratase was purified for a detailed characterization. A 3-step purification process subjected the debris-free homogenate of the disrupted cells to ammonium sulfate fractionation, Q-Sepharose ion exchange chromatography and phenyl-Sepharose hydrophobic interaction chromatography. The protein concentration, enzyme activity, the specific enzyme activity, recovery yield and the purification factor at various stages of the purification process are shown in Table 1 .

Ammonium sulfate precipitation removed a lot of unwanted proteins, and $70 \%$ of the initial enzyme activity of the crude extract was recovered from the final precipitate (Table 1). The purification factor at this stage was 1.4

Table 1 Purification of intracellular nitrile hydratase from $R$. erythropolis

\begin{tabular}{lrllll}
\hline $\begin{array}{l}\text { Purification } \\
\text { step }\end{array}$ & $\begin{array}{l}\text { Total } \\
\text { protein } \\
(\mathrm{mg})\end{array}$ & $\begin{array}{l}\text { Total } \\
\text { enzyme } \\
\text { activity } \\
(\mathrm{U})\end{array}$ & $\begin{array}{l}\text { Total } \\
\text { specific } \\
\text { activity } \\
(\mathrm{U} / \mathrm{mg})\end{array}$ & $\begin{array}{l}\text { Yield } \\
(\%)\end{array}$ & $\begin{array}{l}\text { Purification } \\
\text { factor }\end{array}$ \\
\hline $\begin{array}{l}\text { Cell-free extract } \\
\begin{array}{l}\text { Ammonium sulfate } \\
\text { precipitation }\end{array}\end{array}$ & 520 & 8.8 & 0.017 & 70 & 1.4 \\
$\begin{array}{l}\text { Q-Sepharose column } \\
\text { Phenyl-Sepharose }\end{array}$ & 220 & 6.0 & 0.027 & 48 & 2.3 \\
\hline
\end{tabular}

(Table 1). At the final step of purification, the purification factor was nearly 11 and about $18 \%$ of the total initial activity was recovered (Table 1 ).

Characterization of the purified nitrile hydratase

\section{Molecular weight}

The apparent molecular mass of the purified nitrile hydratase was determined by gel filtration chromatography on a Sephacryl S200 column that had been pre-calibrated with the standard protein molecular weight markers. The molecular weight of the native enzyme was $65 \mathrm{kDa}$. For nitrile hydratase of Rhodococcus equi A4, an approximate molecular weight of $74 \mathrm{kDa}$ has been reported (Přepechalová et al., 2001). The purified enzyme recovered from the gel filtration column was concentrated and used to determine the molecular weights of the subunits $\alpha$ and $\beta$. The silver stained denaturing SDS-PAGE gel for the purified enzyme is shown in Fig. 1. The purified enzyme exhibited two distinct bands with molecular weights of approximately 29 and $30 \mathrm{kDa}$ (Fig. 1, lane 5), confirming the presence of two subunits. The $\alpha$-subunit of nitrile hydratase of $R$. rhodochrous has been previously reported to be lighter in weight than the $\beta$-subunit (Nagasawa et al. 1991;

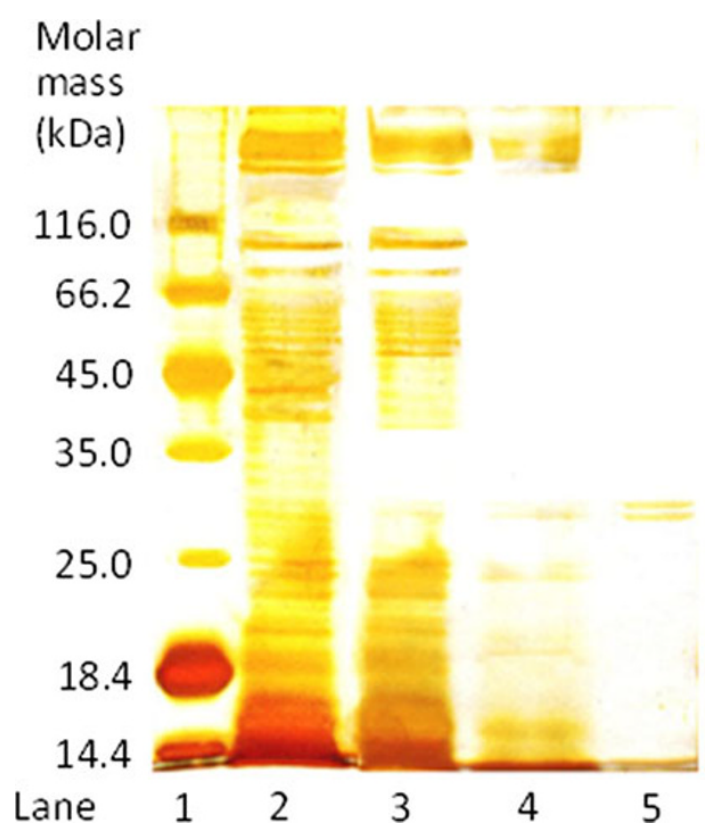

Fig. 1 SDS-PAGE of cell protein extract at various stages of purification. Lane 1 standard protein molecular weight markers (lysozyme, $14.4 \mathrm{kDa} ; \beta$-lactoglobulin, $18.4 \mathrm{kDa}$; REase Bsp98 1, $25.0 \mathrm{kDa}$; lactate dehydrogenase, $35.0 \mathrm{kDa}$; ovalbumin, $45.0 \mathrm{kDa}$; bovine serum albumin, $66.2 \mathrm{kDa} ; \beta$-galactosidase, $116.0 \mathrm{kDa}$ ). Lane 2 crude cell-free extract. Lane 3 ammonium sulfate fractionation. Lane 4 Q-Sepharose column fraction. Lane 5 phenyl-Sepharose column fraction 
Prasad et al. 2009) therefore, by analogy, the subunit with a molecular weight of around $29 \mathrm{kDa}$ was assumed to be the $\alpha$, and the other to be the $\beta$.

\section{Temperature and pH optima}

The effect of temperature (Cramp et al. 1997; Nagasawa et al. 1986; Prasad et al. 2009) and pH (Přepechalová et al. 2001; Hjort et al. 1990) on nitrile hydratase activity from various microbial sources has also been reported in literature. The relative activity of nitrile hydratase at various incubation temperatures is shown in Fig. 2. The temperature for peak activity was $20{ }^{\circ} \mathrm{C}$ (Fig. 2), but the temperature range for maximum activity was relatively broad at $20-25{ }^{\circ} \mathrm{C}$ (Fig. 2). At temperatures of $>30{ }^{\circ} \mathrm{C}$, the activity was reduced likely, because the elevated temperature adversely affected the stability of the enzyme. This might be due to thermal deactivation of the protein molecules. The thermostability of the purified enzyme was measured at various incubation temperatures (Fig. 3). The enzyme was clearly prone to increasing denaturation with the increasing temperature in the range of $25-30{ }^{\circ} \mathrm{C}$. The relevant data are shown in Table 2. The thermal deactivation constant $\left(k_{\mathrm{d}}, \mathrm{h}^{-1}\right)$ of the enzyme at various temperatures was estimated from the slope of a semilog plot of the enzyme activity versus time. The half-life $\left(t_{1 / 2}, \mathrm{~h}\right)$ of the enzyme was then estimated using the following equation:

$t_{1 / 2}=\frac{0.693}{k_{\mathrm{d}}}$

The half-lives of ferric type nitrile hydratases have been reported as $2.6 \mathrm{~h}$ and $15 \mathrm{~min}$ at 20 and $30^{\circ} \mathrm{C}$, respectively (Nagamune et al. 1990). Generally, cobalt-type nitrile hydratases are relatively more thermostable than the ferric type nitrile hydratase. The reported half-life of nitrile

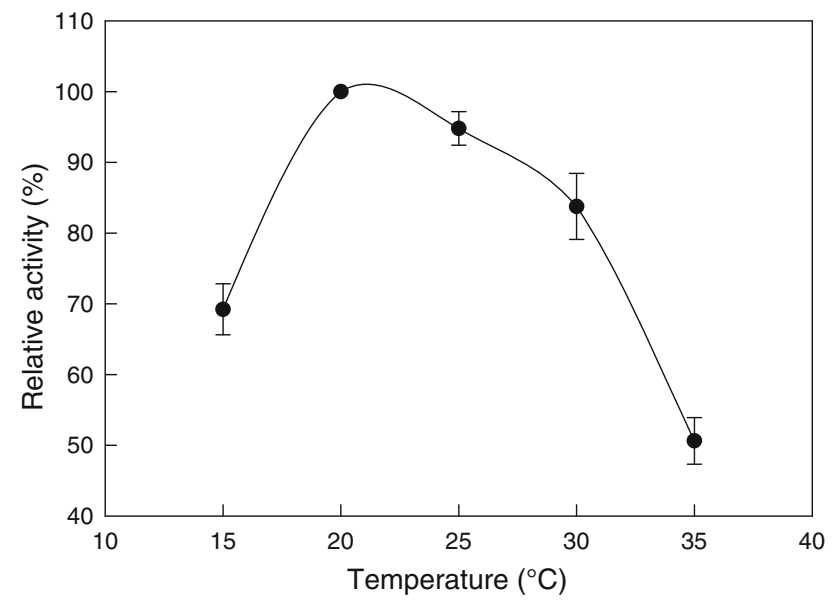

Fig. 2 Activity-temperature profile of nitrile hydratase measured at pH 7.0 (20 mM phosphate buffer)

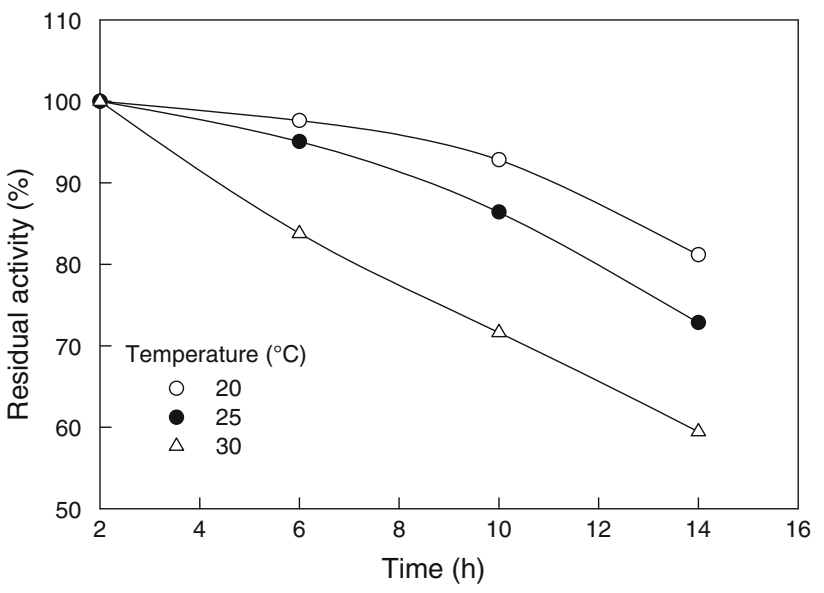

Fig. 3 Residual activity of nitrile hydratase versus time at different incubation temperatures. The $\mathrm{pH}$ was 7.0

Table 2 Thermal deactivation constant and half-life of nitrile hydratase at various temperatures $(\mathrm{pH} 7.0,20 \mathrm{mM}$ phosphate buffer)

\begin{tabular}{lll}
\hline Temperature $\left({ }^{\circ} \mathrm{C}\right)$ & $\begin{array}{l}\text { Thermal deactivation } \\
\text { constant, } k_{\mathrm{d}}\left(\mathrm{h}^{-1}\right)\end{array}$ & Half-life, $t_{1 / 2}(\mathrm{~h})$ \\
\hline 20 & 0.018 & 38.5 \\
25 & 0.027 & 25.7 \\
30 & 0.041 & 16.9 \\
\hline
\end{tabular}

hydratase from Bacillus pallidus Dac521 at $30{ }^{\circ} \mathrm{C}$ was $40 \mathrm{~h}$ (Cramp et al. 1997). Half-life of nitrile hydratase from $R$. rhodochrous PA-34 was reported to be $2 \mathrm{~h}$ at $40^{\circ} \mathrm{C}$ and $0.5 \mathrm{~h}$ at $50^{\circ} \mathrm{C}$ (Prasad et al. 2009). The nitrile hydratase from Brevibacterium R-312 had half-lives of 240 and $48 \mathrm{~h}$ at 10 and $25^{\circ} \mathrm{C}$, respectively (Nagasawa et al. 1986).

$\mathrm{pH}$ is one of the most important factors influencing the side groups of the amino acid dissociation in the protein structure. The optimum $\mathrm{pH}$ for nitrile hydratase activity was determined by measuring the relative enzyme activity in buffers of different $\mathrm{pH}$ values. The optimum $\mathrm{pH}$ for the nitrile hydratase activity was 7.0 , but the enzyme remained fairly active up to a $\mathrm{pH}$ of 7.5 (Fig. 4). The enzyme was also most stable at a pH of 7.0 (Fig. 5). Both higher and lower $\mathrm{pH}$ values reduced stability (Fig. 5).

The half-life $\left(t_{1 / 2}\right)$ of the nitrile hydratase at different $\mathrm{pH}$ values was estimated from the slopes of the semilog plots of residual activity versus time, as explained above. The relevant data are shown in Table 3.

\section{Substrate specificity}

The substrate activity spectrum of nitrile hydratases from different sources can be quite different (Přepechalová et al. 2001; Bui et al. 1984; Asano et al. 1982; Nagasawa et al. 1987, 1986; Hjort et al. 1990). The activity of purified nitrile hydratase toward various nitriles (Table 4) was 


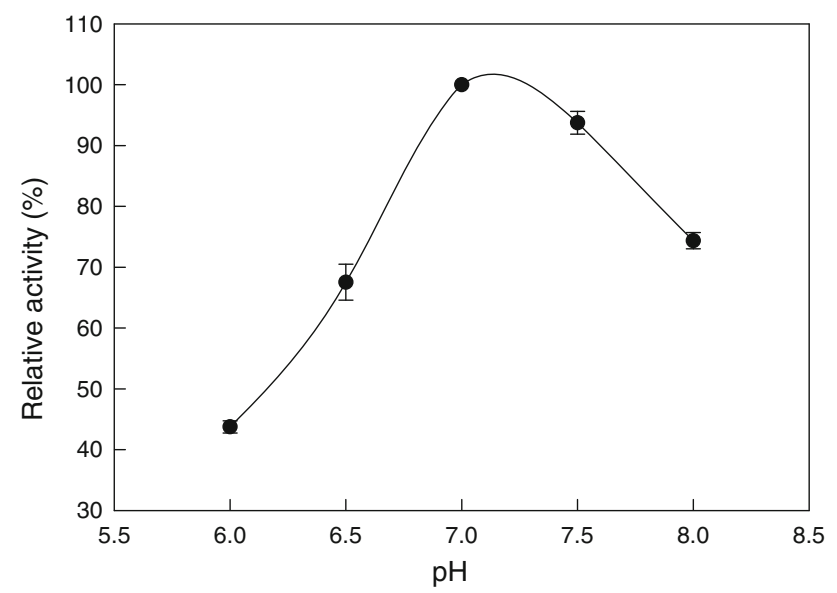

Fig. 4 The activity-pH profile for nitrile hydratase at $20{ }^{\circ} \mathrm{C}$

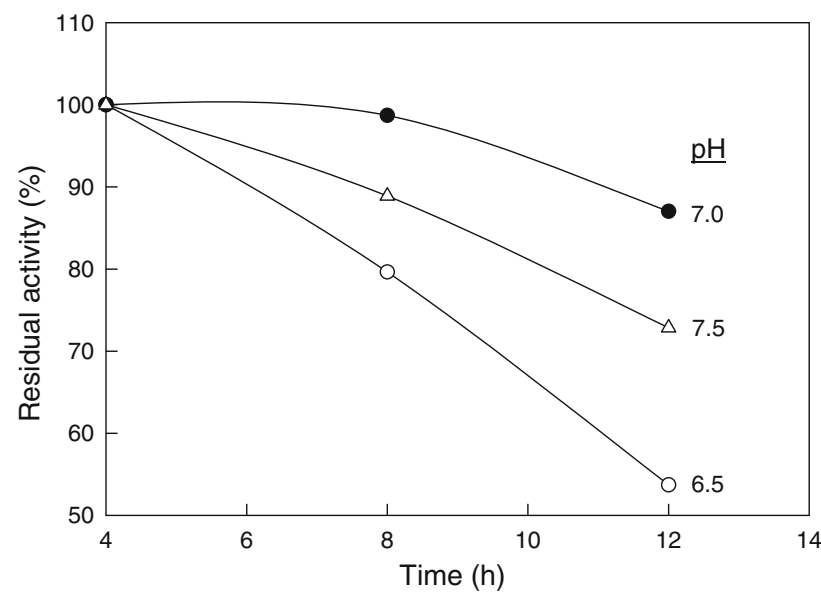

Fig. 5 Residual activity of nitrile hydratase versus time at various values of the incubation $\mathrm{pH}$. The temperature was $20^{\circ} \mathrm{C}$

Table 3 Half-life of nitrile hydratase at $20^{\circ} \mathrm{C}$ and different $\mathrm{pH}$ values

\begin{tabular}{ll}
\hline $\mathrm{pH}$ & Half-life, $t_{1 / 2}(\mathrm{~h})$ \\
\hline 6.5 & 12 \\
7.0 & 38 \\
7.5 & 22 \\
\hline
\end{tabular}

examined. The conversion of 3-cyanopyridine was taken to be $100 \%$. All other relative activity data (Table 4) are relative to the conversion of 3-cyanopyridine.

The enzyme displayed good activity toward aromatic nitriles, such as benzonitrile, 4-cyanopridine, 3-cyanopyridine and pyrazinonitrile (Table 4), but was less active on 3 -aminobenzonitrile. The enzyme was quite active on the aliphatic nitrile, i.e., isobutyronitrile, but less on acetonitrile. The enzyme was completely inactive on aliphatic
Table 4 Substrate specificity of nitrile hydratase from $R$. erythropolis

\begin{tabular}{lcc}
\hline Type of nitrile & Structure & Relative activity $^{\mathrm{a}}(\%)$ \\
\hline $\begin{array}{l}\text { Aliphatic nitrile } \\
\text { Acetonitrile }\end{array}$ & $\mathrm{H}_{3} \mathrm{C}-\mathrm{CN}$ & 54 \\
Isobutyronitrile & $\left(\mathrm{CH}_{3}\right)_{2} \mathrm{HC}-\mathrm{CN}$ & 110 \\
Aromatic nitrile & \\
Benzonitrile &
\end{tabular}

3-Aminobenzonitrile<smiles>N#Cc1cccc(N)c1</smiles>

4-Cyanopyridine<smiles>N#Cc1ccncc1</smiles><smiles>N#Cc1cccnc1</smiles>

Pyrazinonitrile<smiles>N#Cc1cnccn1</smiles>

94

Dinitrile

Succinonitrile<smiles>N#CCC#N</smiles>

0

Adiponitrile<smiles>N#CCC#N</smiles>

0

${ }^{a}$ Measured at $\mathrm{pH} 7.0\left(20 \mathrm{mM}\right.$ phosphate buffer), $20{ }^{\circ} \mathrm{C}$, after $30 \mathrm{~min}$. The initial substrate concentration was always $2 \mathrm{mM}$

dinitriles (Table 4). The meta substitution of benzonitrile with an amino group reduced activity (Table 4), possibly as a consequence of the electron-donating effect of the substituent. The position of the substituent on the aromatic ring is known to affect activity as observed for nitrile hydratase of Rhodococcus equi A4 (Přepechalová et al. 2001). 


\section{Effect of metal ions and inhibitors}

It is evident from Table 5 that the presence of various metal ions enhanced the enzyme activity. Cobalt(II) had the strongest enhancing effect. The metal ion chelating agent EDTA had a strong inhibitory effect, presumably because it bound the $\mathrm{Co}(\mathrm{III})$ at the active site of the enzyme. Urea was found to be a weak inhibitor of the enzyme (Table 5). Effect of metal ions on nitrile hydratase activity has been widely reported in literature (MaierGreiner et al. 1991; Cramp et al. 1997; Wieser et al. 1998).

\section{Kinetic constants}

The Michaelis-Menten constants $K_{\mathrm{m}}$ and $v_{\max }$ values were determined by plotting the initial reaction rate $(v)$ versus

Table 5 Effect of metal ions and inhibitors on the nitrile hydratase activity

\begin{tabular}{ll}
\hline Metal ion or inhibitor & Relative activity ${ }^{\mathrm{a}}(\%)$ \\
\hline $\mathrm{None}$ & 100 \\
$\mathrm{CoCl}_{2}$ & 215 \\
$\mathrm{FeCl}_{3}$ & 174 \\
$\mathrm{FeSO}_{4}$ & 183 \\
$\mathrm{NaCl}$ & 194 \\
Urea & 91 \\
EDTA & 34 \\
2-Mercaptoethanol & 68 \\
\hline
\end{tabular}

${ }^{\text {a }}$ Measured in phosphate buffer $(\mathrm{pH} 7.0,20 \mathrm{mM})$ at $20{ }^{\circ} \mathrm{C}$, after $30 \mathrm{~min}$ of reaction using 3 -cyanopyridine with various metal ions at an initial concentration of $2 \mathrm{mM}$

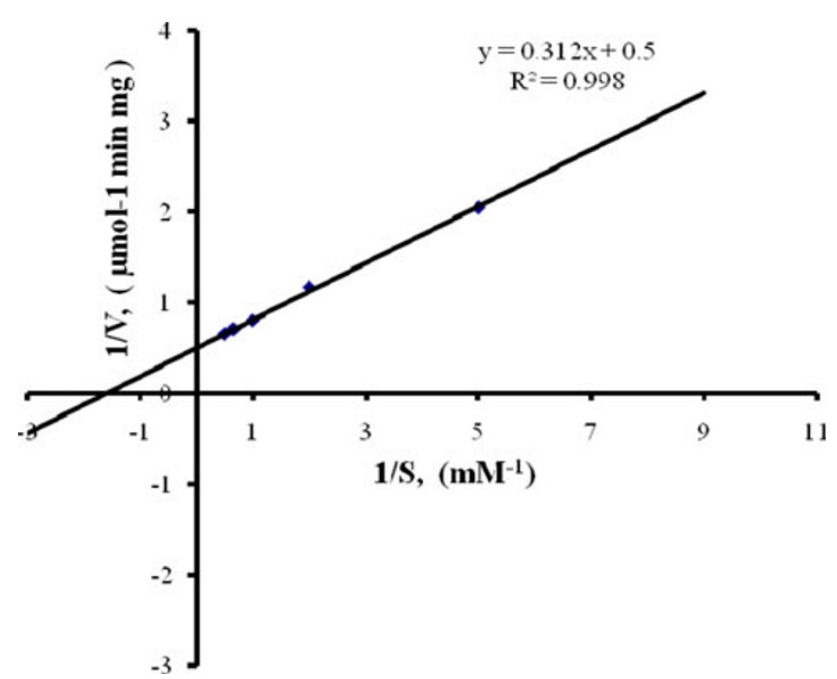

Fig. 6 A Lineweaver-Burk plot for biotransformation of 3-cyanopyridine to nicotinamide using nitrile hydratase. The reciprocal of the initial reaction rate $(v)$ is plotted against the reciprocal of the initial substrate concentration $S$. The data were measured at $\mathrm{pH} 7.0,20^{\circ} \mathrm{C}$ the initial substrate concentration $(S)$ in the form of a $\mathrm{Li}$ neweaver-Burk plot (Fig. 6). The substrate was 3-cyanopyridine and its concentration ranged from 0.2 to $2.0 \mathrm{mM}$. The reaction was carried out at $\mathrm{pH} 7.0(20 \mathrm{mM}$ phosphate buffer) and $25{ }^{\circ} \mathrm{C}$. The $K_{\mathrm{m}}$ and $v_{\max }$ values were $0.624 \mathrm{mM}$ and $5.12 \mu \mathrm{mol} / \mathrm{min} / \mathrm{mg}$, respectively. The $K_{\mathrm{m}}$ value obtained in this work was within the range reported for nitrile hydratases from other microorganisms (Wieser et al. 1998; Mayaux et al. 1990; Watanabe et al. 1987; Pereira et al. 1998; Sachi and Lindsay 2007; Feng et al. 2008). The $v_{\max }$ value of nitrile hydratase of Brevibacterium $\mathrm{R} 312$ acting on 3-cyanopyridine was reported to be $5 \mu \mathrm{mol} / \mathrm{min} /$ mg (Mayaux et al. 1990) or only about $50 \%$ of the value found in the present study.

Biotransformation of nitriles using whole cells

The use of freely-suspended whole cells and alginate matrix immobilized whole cells of $R$. erythropolis was examined for biotransformation of nitriles because it eliminated the expense of recovering and purifying the nitrile hydratase enzyme from the cells. Biotransformation catalyzed by whole cells is discussed in the following sections.

\section{Freely-suspended whole cells}

Washed whole cells recovered from the fermentation broth were suspended in phosphate buffer $(20 \mathrm{mM}, \mathrm{pH} 7.0)$ at a concentration of $190 \mathrm{mg} / \mathrm{L}$. In different experiments, different nitriles were added to the reaction mixture to obtain an initial concentration of 30,60 and $90 \mathrm{mM}$. The reaction mixture was continuously stirred $(160 \mathrm{rpm})$ and incubated at $25{ }^{\circ} \mathrm{C}$. The percent conversion for the various substrates after 24 and $48 \mathrm{~h}$ of the reaction is shown in Table 6 . For all substrates, the conversion increased with time (Table 6), as expected. In all cases, the conversion at a given time was reduced with an increase in the initial concentration of the substrate (Table 6). For all the substrate tested, a conversion of $\geq 80 \%$ could be achieved within $24 \mathrm{~h}$ starting with an initial substrate concentration of $30 \mathrm{mM}$ (Table 6). An earlier study reported on the biotransformation of 3-cyanopyridine to nicotinamide using freely-suspended whole cells of $R$. erythropolis (Kamble and Banerjee 2008). A substrate conversion of $93 \%$ was achieved under statistically optimized reaction conditions.

\section{Immobilized whole cells}

Optimization of reaction parameters Immobilization allows the cells to be reused relatively easily and often improves the half-life of the biocatalyst (Adinarayana et al. 
Table 6 Effect of nitrile type and concentration on percent conversion to the corresponding amide using free cells of $R$. erythropolis

\begin{tabular}{|c|c|c|c|c|c|c|}
\hline \multirow[t]{3}{*}{ Nitrile } & \multicolumn{6}{|c|}{ Reaction time } \\
\hline & \multicolumn{3}{|l|}{$24 \mathrm{~h}$} & \multicolumn{3}{|l|}{$48 \mathrm{~h}$} \\
\hline & $30 \mathrm{mM}$ & $60 \mathrm{mM}$ & $90 \mathrm{mM}$ & $30 \mathrm{mM}$ & $60 \mathrm{mM}$ & $90 \mathrm{mM}$ \\
\hline Benzonitrile & $95 \pm 0.7$ & $82 \pm 2.1$ & $77 \pm 1.4$ & $96 \pm 1.4$ & $91 \pm 1.4$ & $87 \pm 2.1$ \\
\hline 4-Cyanopyridine & $88 \pm 1.4$ & $77 \pm 2.1$ & $75 \pm 1.4$ & $94 \pm 1.4$ & $80 \pm 1.4$ & $76 \pm 1.4$ \\
\hline Pyrazinonitrile & $80 \pm 1.4$ & $73 \pm 1.4$ & $65 \pm 1.4$ & $88 \pm 1.4$ & $77 \pm 0.7$ & $68 \pm 1.4$ \\
\hline Isobutyronitrile & $83 \pm 0.7$ & $90 \pm 0.7$ & $79 \pm 1.4$ & $81 \pm 0.7$ & $88 \pm 1.4$ & $77 \pm 2.1$ \\
\hline
\end{tabular}

2005; Kaul et al. 2006; Vejvoda et al. 2006; Fatima et al. 2007; Ahmed 2008; Bhattacharyya et al. 2010). Furthermore, the immobilized cells are relatively easily retained in a continuous flow biotransformation reactor. This was the rationale of evaluation of immobilized cells for nitrile biotransformations in this study.

Alginate concentration Different concentrations (1.0$2.5 \%, \mathrm{~g} / 100 \mathrm{~mL}$ ) of alginate were tested for preparing the gel matrix for immobilizing the cells. In all cases, the bead diameter was $2 \mathrm{~mm}$ and the cell loading in the gel matrix was $190 \mathrm{mg} / \mathrm{mL}$. The beads were tested for the conversion of 3-caynopyridine to nicotinamide at $25^{\circ} \mathrm{C}$ in $\mathrm{pH} 7.0$ buffer (50 mM Tris- $\mathrm{HCl}$ ) for $24 \mathrm{~h}$. Beads made with 1.5 and $2 \%$ alginate concentration achieved the highest conversion of $86 \%$ (Fig. 7a). The conversion was lower at an alginate concentration of $<1.5 \%$, possibly because of a reduced entrapment of the cells in the softer beads. The conversion was also reduced if the alginate concentration exceeded $2 \%$ (Fig. 7a) likely, because of increased diffusional limitation within the beads. A decreased mass transfer and conversion have been previously reported for beads made with a high concentration of alginate (Srinivasulu et al. 2003). In view of the results in Fig. 7a, an alginate concentration of $2 \%$ was used in all future experiments.

Selection of buffer strength Different strengths (20, 50, $100,150$ and $200 \mathrm{mM})$ of Tris- $\mathrm{HCl}$ buffer $(\mathrm{pH} 7.0)$ were evaluated for the biotransformation with immobilized cells. The biocatalyst beads and the reaction conditions were as described in the previous section. The results are shown in Fig. 7b. A buffer concentration of $50 \mathrm{mM}$ (Tris- $\mathrm{HCl}$ buffer, $\mathrm{pH}$ 7.0) provided a conversion of $90 \%$ and was therefore selected for all future work.

Bead size Bead size affects mass transfer within the bead and the fraction of the cells in the bead volume that can be used effectively for a reaction. Therefore, the effect of bead size on the reaction was evaluated. Beads of different sizes (1-5 mm) were generated using syringes with different orifice sizes. The reaction conditions were: $2 \%$ alginate concentration in the beads, $50 \mathrm{mM}$ (Tris- $\mathrm{HCl}$ buffer, $\mathrm{pH}$ 7.0), a cell loading of $190 \mathrm{mg} / \mathrm{mL}, 25{ }^{\circ} \mathrm{C}, 3$-caynopyridine at an initial concentration of $22 \mathrm{mM}$. The conversion after $24 \mathrm{~h}$ was the highest with beads having a diameter of 1-3 mm (Fig. 7c). As the bead diameter reduced, the surface to volume ratio increased and therefore the mass transfer per unit volume improved. This explained the higher conversion with the smaller beads. A bead size of $3 \mathrm{~mm}$ was selected for all further work, as these relatively large beads were easier to handle and physically more stable than the smaller beads.

Substrate concentration The effect of the initial substrate concentration (50-100 mM, 3-caynopyridine) on the biotransformation reaction was tested using 3-mm beads. The other reaction conditions were as in the previous section. At $50 \mathrm{mM}$ substrate concentration, the conversion exceeded $90 \%$, but higher concentrations of the substrate reduced conversion (Fig. 7e). The decrease in the conversion at high substrate level may be due to substrate inhibition of the enzyme. Therefore, a $50 \mathrm{mM}$ substrate concentration was selected for all further work.

Cell mass concentration Using beads of $3 \mathrm{~mm}$ diameter, the effect of cell loading $(200,250,300,350,400$ and $450 \mathrm{mg} / \mathrm{mL}$ ) in the gel matrix, on the conversion of 3 -cyanopyridine to nicotinamide was assessed. The reaction conditions were: $25^{\circ} \mathrm{C}, \mathrm{pH} 7.0(50 \mathrm{mM}$ Tris- $\mathrm{HCl}$ buffer), $2 \%$ alginate in the gel matrix and $50 \mathrm{mM}$ initial substrate concentration. The cell loadings of 200 and $250 \mathrm{mg} / \mathrm{mL}$ provided good conversion (95\%) of 3-cyanopyridine (Fig. 7d). Higher cell loading likely impeded mass transfer of the substrate and product within the bead and were therefore less effective. Similar effects of cell loading in gel beads have been previously reported (Lee et al. 1995). In view of the results (Fig. 7d), a cell loading of $200 \mathrm{mg} / \mathrm{mL}$ was selected for all further work.

Effect of bead hardening treatments To increase the stability of the beads and their potential for reuse, the surface 

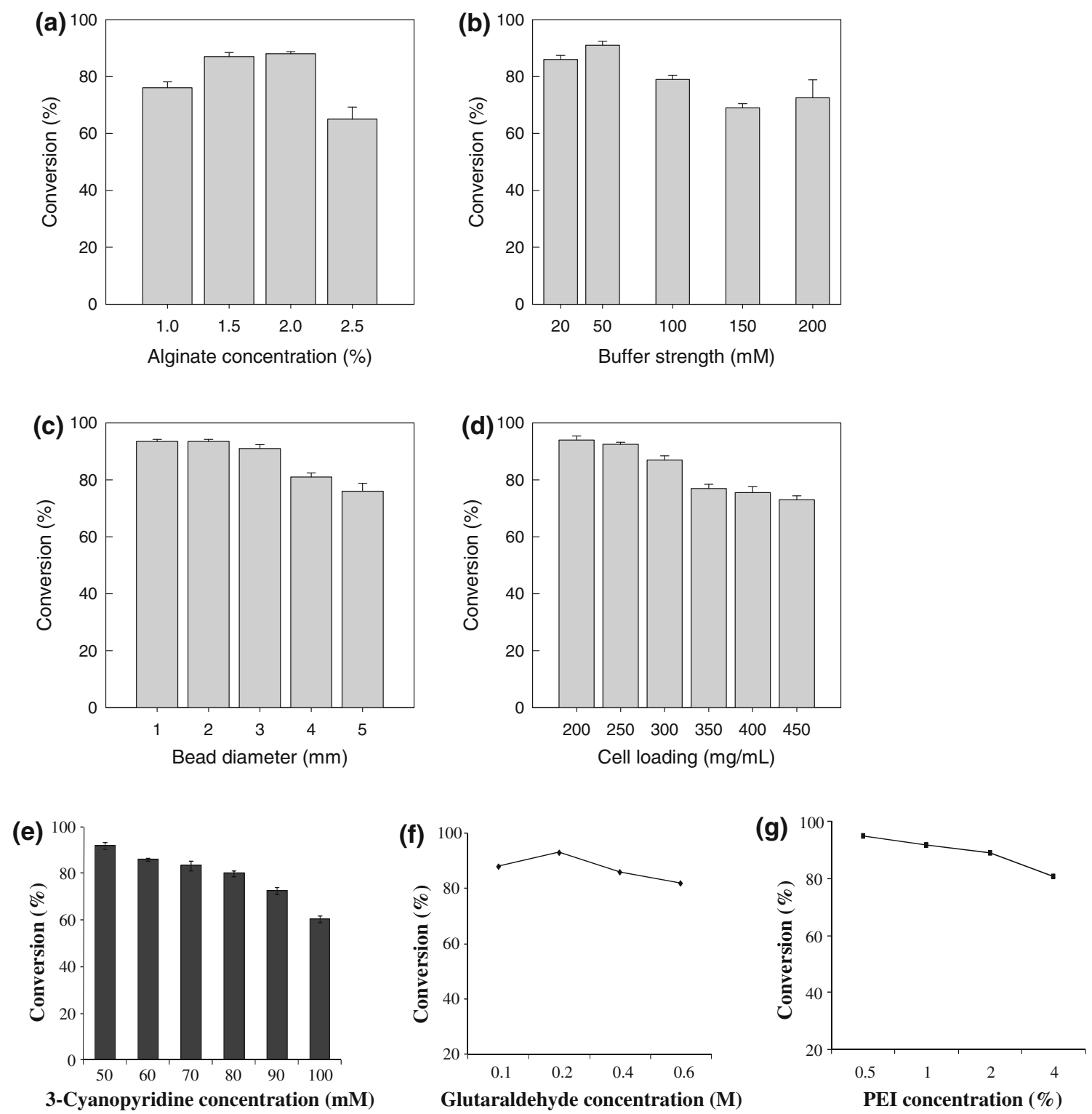

Fig. 7 Conversion of 3-cyanopyridine at $24 \mathrm{~h}\left(25^{\circ} \mathrm{C}, \mathrm{pH} 7.0\right)$ using a different alginate concentrations in the beads, $\mathbf{b}$ different concentrations of the Tris- $\mathrm{HCl}$ buffer in the reaction medium, $\mathbf{c}$ different bead sizes ( $2 \%$ alginate in beads), $\mathbf{d}$ different cell loadings in the beads, e different substrate (3-cyanopyridine) concentrations, $\mathbf{f}$ different glutaraldehyde concentration, $\mathbf{g}$ different polyethyleneimine concentration crosslinking with glutaraldehyde and polyethyleneimine have been reported in literature (Hann et al. 2002). In this work the beads with the immobilized cells were crosslinked by suspending in a mixture of glutaraldehyde $(0.2 \mathrm{M})$ and $0.5 \%(\mathrm{~g} / 100 \mathrm{~mL})$ polyethyleneimine for $1 \mathrm{~h}$ at room temperature. Afterwards, the beads were repeatedly washed with deionized water and used for the hydration of 3-cyanopyridine. The reaction conditions were: $25{ }^{\circ} \mathrm{C}, \mathrm{pH} 7.0(50 \mathrm{mM}$ Tris- $\mathrm{HCl}$ buffer $), 2 \%$ alginate in the gel matrix, $200 \mathrm{mg} / \mathrm{mL}$ cell loading and $50 \mathrm{mM}$ initial substrate concentration. A substrate conversion of
$>95 \%$ could be achieved with the cross-linked immobilized beads (Fig. 7f, g).

Using the cross-linked beads, the biotransformation of different substrates (Table 7) at different initial concentrations $(60,100$ and $150 \mathrm{mM})$ was tested in separate experiments. The reaction conditions were: $25^{\circ} \mathrm{C}, \mathrm{pH} 7.0$ (50 mM Tris- $\mathrm{HCl}$ buffer), $2 \%$ alginate in the gel matrix and a cell loading in the beads of $200 \mathrm{mg} / \mathrm{mL}$. For the aromatic nitriles (i.e., benzonitrile, 4-cyanopyridine, pyrazinonitrile), the conversion was generally good up to a substrate concentration of $100 \mathrm{mM}$ (Table 7). A further 
Table 7 Effect of nitrile type and concentration on percent conversion to the corresponding amide using immobilized cells of $R$. erythropolis

\begin{tabular}{|c|c|c|c|c|c|c|}
\hline \multirow[t]{3}{*}{ Nitrile } & \multicolumn{6}{|c|}{ Reaction time } \\
\hline & \multicolumn{3}{|l|}{$24 \mathrm{~h}$} & \multicolumn{3}{|l|}{$48 \mathrm{~h}$} \\
\hline & $60 \mathrm{mM}$ & $100 \mathrm{mM}$ & $150 \mathrm{mM}$ & $60 \mathrm{mM}$ & $100 \mathrm{mM}$ & $150 \mathrm{mM}$ \\
\hline Benzonitrile & $89 \pm 1.4$ & $81 \pm 1.4$ & $80 \pm 1.4$ & $97 \pm 0.7$ & $88 \pm 1.4$ & $84 \pm 0.7$ \\
\hline 4-Cyanopyridine & $79 \pm 0.7$ & $66 \pm 0.7$ & $62 \pm 0.7$ & $94 \pm 1.4$ & $88 \pm 0.7$ & $80 \pm 1.4$ \\
\hline Pyrazinonitrile & $81 \pm 2.1$ & $66 \pm 1.4$ & $61 \pm 1.4$ & $89 \pm 1.4$ & $79 \pm 1.4$ & $75 \pm 1.4$ \\
\hline Isobutyronitrile & $98 \pm 1.4$ & $95 \pm 1.4$ & $88 \pm 0.7$ & $96 \pm 1.4$ & $92 \pm 1.4$ & $73 \pm 0.7$ \\
\hline
\end{tabular}

increase in the initial concentration of the substrate reduced conversion. For the non-aromatic isobutyronitrile, the conversion was generally higher than for the aromatic substrates (Table 7). A comparison of Tables 6 and 7 shows that at a given concentration of the substrate the immobilized cells were more effective than the freelysuspended cells for these biotransformations. Unlike the freely-suspended cells, the immobilized cells could of course be reused relatively easily. Immobilization in beads improved the cells' tolerance toward the substrates.

\section{Use of packed bed reactor for the nitrile conversion}

A vertically mounted jacketed packed bead reactor (length $18 \mathrm{~cm}$, diameter $2.6 \mathrm{~cm}$, working volume $96 \mathrm{~mL}$ ) was used in these experiments. The bed was packed with the alginate beads ( $3 \mathrm{~mm}$ diameter, $2 \%$ alginate in beads, $200 \mathrm{mg} / \mathrm{mL}$ cell loading in the gel matrix). The substrate was fed at the bottom of the reactor using a peristaltic pump. The substrate concentration in the feed was always $100 \mathrm{mM}$ and the substrate was dissolved in buffer ( $\mathrm{pH} 7.0,50 \mathrm{mM}$ Tris$\mathrm{HCl})$. The reactor was maintained at $25^{\circ} \mathrm{C}$. The effect of the substrate flow rate on conversion and the reusability of the immobilized beads were evaluated.

Effect of flow rate on conversion The substrate flow rate $(2.5,5.0$ and $7.5 \mathrm{~mL} / \mathrm{h})$ affected the conversion as shown in Fig. 8 for the different nitriles. For the flow rate values of 2.5, 5.0 and $7.5 \mathrm{~mL} / \mathrm{h}$, the residence times in the reactor were 38, 19.4 and $12.8 \mathrm{~h}$, respectively. Conversion generally decreased with the increase in substrate flow rate, as the residence time, or the time available for the reaction, reduced (Chang et al. 2009). A flow rate of $2.5 \mathrm{~mL} / \mathrm{h}$ afforded good conversion of benzonitrile and 4-cyanopyridine (Fig. 8).

For isobutyronitrile, the flow rate for optimal conversion was $5 \mathrm{~mL} / \mathrm{h}$. Lower and higher flow rates reduced conversion (Fig. 8). A reduced conversion as a consequence of an increased flow rate is of course easily understood in terms of a reduced amount of time available for the reaction. The increased conversion of isobutyronitrile with an
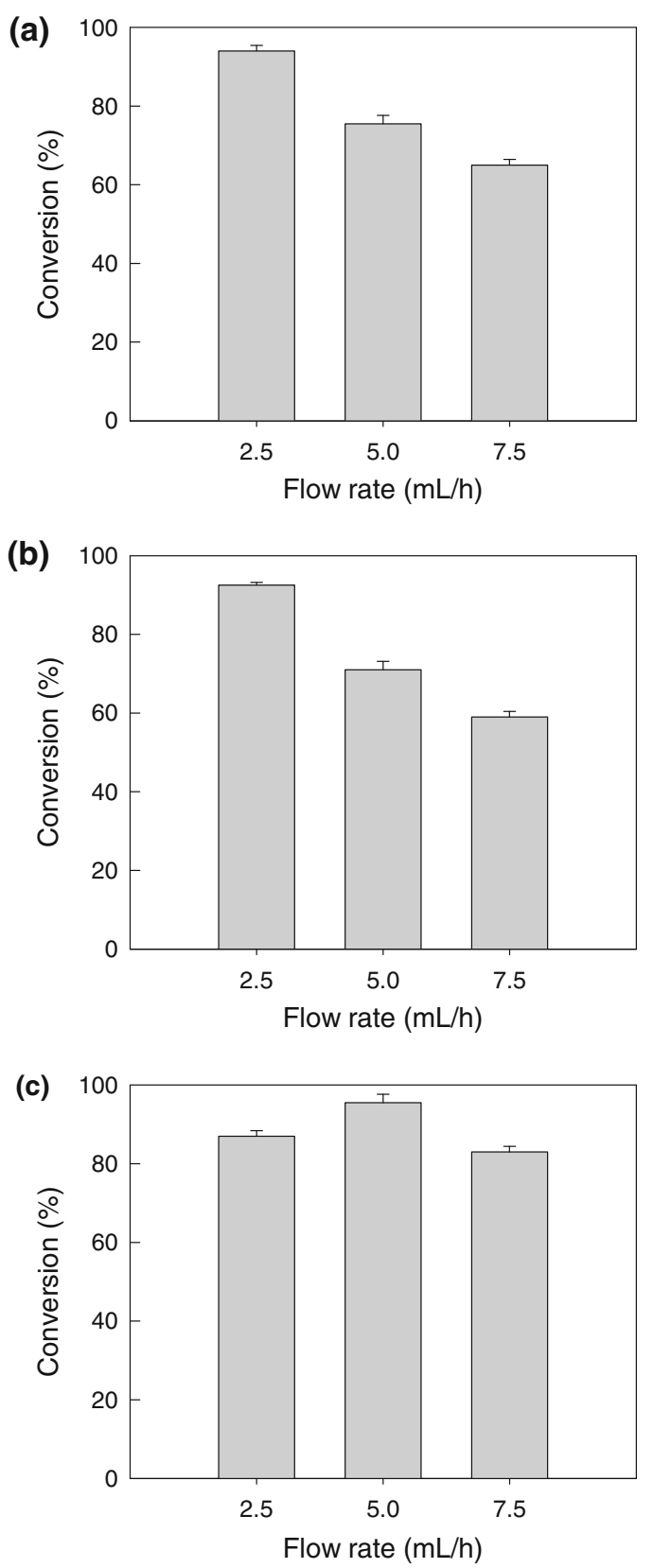

Fig. 8 Effect of substrate flow rate in the packed bed on the conversion of: a benzonitrile, $\mathbf{b}$ 4-cyanopyridine and $\mathbf{c}$ isobutyronitrile 
increase in flow rate from 2.5 to $5.0 \mathrm{~mL} / \mathrm{h}$ at first seems unusual. In shake flask batch reactors (Table 7), the conversion of this substrate was actually lower at $48 \mathrm{~h}$ compared to the conversion at $24 \mathrm{~h}$. Clearly, therefore, an excessively long reaction time actually reduced conversion of this substrate. This may be a consequence of the equilibrium kinetics of the enzyme-catalyzed reactions.

The packed bed reactor had a superior performance compared to the batch reactors (Table 7). For example, for benzonitrile and 4-cyanopyridine, at a residence time of $38 \mathrm{~h}$ (i.e., a flow rate of $2.5 \mathrm{~mL} / \mathrm{h}$ ) in the packed reactor, the conversion was $>90 \%$ (Fig. 8). For the same substrates at $48 \mathrm{~h}$ (Table 7) starting with a substrate concentration of $100 \mathrm{mM}$ as in the packed bed, the conversion values were much lower: $81 \%$ for benzonitrile and $66 \%$ for 4-cyanopyridine (Table 7). Similarly, using isobutyronitrile the conversion in the packed bed was $95 \%$ at a residence time of $\sim 19$ h (i.e., a flow rate of $5.0 \mathrm{~mL} / \mathrm{h}$; Fig. 8), but in the batch rector the same conversion was achieved in $24 \mathrm{~h}$ (Table 7).

Reusability of catalysts The reusability of the freelysuspended cells in shake flasks, the immobilized whole cells in shake flasks and the immobilized cells in the packed bed reactor is compared in Fig. 9. The immobilized cells used in the packed bed had been subjected to the earlier mentioned cross-linking treatment. The data in Fig. 9 are for the conversion of 3-cyanopyridine $(50 \mathrm{mM})$ at $25{ }^{\circ} \mathrm{C}$, pH 7 (50 mM Tris- $\mathrm{HCl}$ buffer). The immobilized beads were $3 \mathrm{~mm}$ in diameter and had been prepared using an alginate concentration of $2 \%$. The cell loading in the beads was $200 \mathrm{mg} / \mathrm{L}$. After each use cycle, the cells and the beads were recovered, washed and reused for the next cycle. With all the catalyst systems, the conversion declined with increasing number of use cycles (Fig. 9). The freely-suspended cells lost activity most rapidly. The

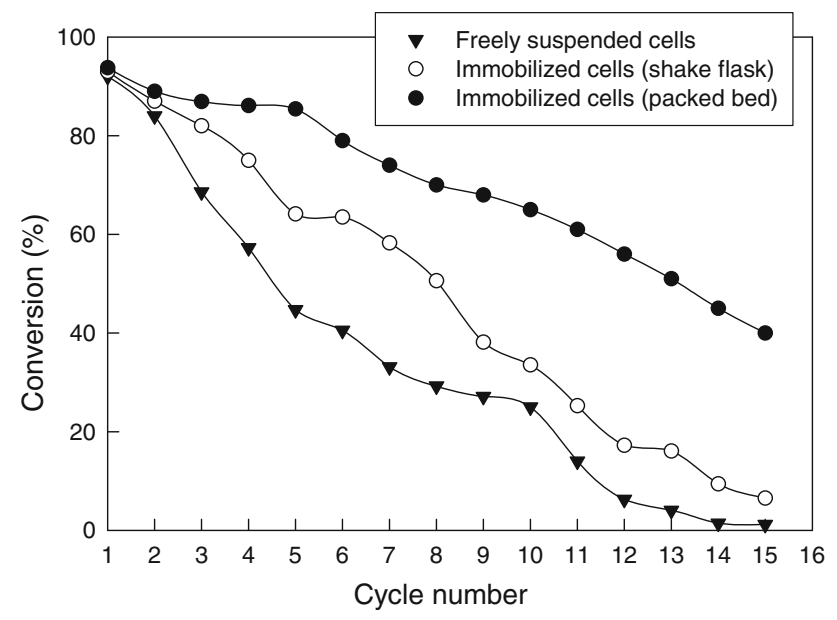

Fig. 9 Effect of reuse cycle number on the conversion achieved by different preparations of the biocatalyst immobilized cells in shake flasks were relatively more stable, but the cross-linked immobilized cells used in the packed bed were clearly the most stable (Fig. 9). The cross-linked immobilized cells in the packed bed could be used for at least six cycles while continuing to achieve a substrate conversion of $\sim 85 \%$.

\section{Concluding remarks}

The intracellular nitrile hydratase of $R$. erythropolis was purified and characterized. The $\mathrm{pH}$ and temperature optima for the enzyme activity were 7.0 and $20^{\circ} \mathrm{C}$, respectively. The enzyme-containing freely-suspended whole cells and the cells immobilized in alginate beads were highly effective in converting various nitriles to amides, but the immobilized cells could be reused. The use of the immobilized cells of $R$. erythropolis MTCC 1526 in packed beds offers an alternative to the traditional chemical processes for converting nitriles to amides.

Acknowledgments ALK, LB, VSM and AS gratefully acknowledge senior research fellowships awarded by the Council of Scientific and Industrial Research and Department of Biotechnology, Government of India.

Conflict of interest The authors declare that they have no conflict of interest.

Open Access This article is distributed under the terms of the Creative Commons Attribution License which permits any use, distribution, and reproduction in any medium, provided the original author(s) and the source are credited.

\section{References}

Adinarayana K, Jyothi B, Ellaiah P (2005) Production of alkaline protease with immobilized cells of $B$. subtilis PE- 11 in various matrices by entrapment technique. AAPS PharmSciTech 6:391-397

Ahmed SA (2008) Invertase production by Bacillus macerans immobilized on calcium alginate beads. J Appl Sci Res 4:1777-1781

Asano Y, Fujishiro K, Tani Y, Yamada H (1982) Aliphatic nitrile hydratase from Arthrobacter sp. J-1: purification and characterization. Agric Biol Chem 46:1165-1174

Bhattacharyya MS, Singh A, Banerjee UC (2010) Immobilization of intracellular carbonyl reductase from Geotrichum candidum for the stereoselective reduction of 1-naphthyl ketone. Bioresour Technol 101:1581-1586

Bradford MM (1976) A rapid and sensitive method for quantisation of microgram amount of protein using the principle of protein-dye binding. Anal Biochem 72:248-254

Brady D, Beeton A, Zeevaart J, Kgaje C, van Rantwijk F, Sheldon RA (2004) Characterization of nitrilase and nitrile hydratase biocatalytic systems. ApplMicrobiol Biotechnol 4:76-85

Bui K, Fradet H, Arnaud A, Galzy P (1984) A nitrile hydratase with a wide substrate spectrum produced by a Brevibacterium sp. J Gen Microbiol 130:89-93

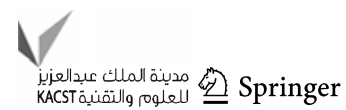


Cantarella M, Cantarella L, Gallifuoco A, Spera A (2006) Use of a UF-membrane reactor for controlling selectively the nitrile hydratase-amidase system in Microbacterium imperial CBS 498-74 resting cells. Case study: benzonitrile conversion. Enzyme Microb Technol 38:126-134

Chang C, Chen J-H, Chang CJ, Wu T-T, Shieh CJ (2009) Optimization of lipase-catalyzed biodiesel by isopropanolysis in a continuous packed-bed reactor using response surface methodology. New Biotechnol 26:87-192

Clifford KH, Geary PJ, Pryce RJ (1993) Process for the preparation of difluorobenzamide.US Patent 5,206,158

Cramp RA, Gilmour M, Cowan DA (1997) Novel thermophilic bacteria producing nitrile-degrading enzymes. Microbiol 143:2313-2320

Dráber P (1991) Quantification of proteins in sample buffer for sodium dodecyl sulfate polyacrylamide gel electrophoresis using colloidal silver. Electrophor 12:453-456

Fatima Y, Kansal H, Banerjee UC (2007) Enantioselective reduction of aryl ketones using immobilized cells of Candida viswanathii. Process Biochem 42:1412-1418

Feng YS, Chen PC, Wen FS, Hsiao WY, Lee CM (2008) Nitrile hydratase from Mesorhizobium sp. F28 and its potential for nitrile biotransformation. Process Biochem 43:1391-1397

Hann EC, Sigmund AE, Hennessey SM, Gavagan JE, Short DR, BenBassat A, Chauhan S, Fallon RD, Payne MS, DiCosimo R (2002) Optimization of an immobilized-cell biocatalyst for production of 4-cyanopentanoic acid. Org Proc Res Dev 6:492-496

Hjort CM, Godtfredsen SE, Emborg C (1990) Isolation and characterization of a nitrile hydratase from a Rhodococcus $\mathrm{sp}$. J Chem Technol Biotechnol 48:217-226

Kamble A, Banerjee UC (2008) Optimization of crucial reaction conditions for the production of nicotinamide by nitrile hydratase using response surface methodology. Appl Biochem Biotechnol 151:143-150

Kaul P, Banerjee A, Banerjee UC (2006) Stereoselective nitrile hydrolysis by immobilized whole-cell biocatalyst. Biomacromolecules 7:1536-1541

Kobayashi M, Shimizu S (2000) Nitrile hydrolyases. Curr Opin Chem Biol 4:95-102

Laemmli UK (1970) Cleavage of structural proteins during the assembly of the head of bacteriophage T4. Nature 227:680-685

Lee W-C, Lee R-Y, Ruaan R-C (1995) Effect of cell concentration on the kinetics of whole-cell enzyme entrapped within calcium alginate. Biotechnol Prog 11:461-464

Lin S-H, Chong ZZ, Maiese K (2001) Nicotinamide: a nutritional supplement that provides protection against neuronal and vascular injury. J Med Food 4:27-38

Maier-Greiner UH, Obermaier-Skrobranek BMM, Estermaier LM, Kammerloher W, Freund C, Wulfing C, Burkert UI, Matern DH, Breuer M, Eulitz M (1991) Isolation and properties of a nitrile hydratase from the soil fungus Myrothecium verrucaria that is highly specific for the fertilizer cyanamide and cloning of its gene. PNAS 88:4260-4264

Mascharak PK (2002) Structural and functional models of nitrile hydratase. Coord Chem Rev 225:201-214

Mayaux J, Cerbelaud E, Soubrier F, Faucher D, Petre D (1990) Purification, cloning, and primary structure of an enantiomer selective amidase from Brevibacterium sp. R312: structural evidence for genetic coupling with nitrile hydratase. J Bacteriol 172:6764-6773

Mylerova V, Martinkova L (2003) Synthetic applications of nitrileconverting enzymes. Curr Org Chem 7:1-17
Nagamune T, Kurata H, Hirata M, Honda J, Hirata A, Endo I (1990) Photosensitive phenomena of nitrile hydratase of Rhodococcus sp. N-771. Photochem Photobiol 51:87-90

Nagasawa T, Ryuno K, Yamada H (1986) Nitrile hydratase of Brevibacterium R312: purification and characterization. Biochem Biophys Res Commun 139:1305-1312

Nagasawa T, Nanba H, Ryuno K, Takeuchi K, Yamada H (1987) Nitrile hydratase of Pseudomonas chlororaphis B23 purification and characterization. Eur J Biochem 162:691-698

Nagasawa T, Takeuchi K, Yamada H (1991) Characterization of a new cobalt-containing nitrile hydratase purified from ureainduced cells of $R$. rhodochrous J1. Eur J Biochem 196:581-589

Nigam VK, Khandelwal AK, Gothwal RK, Mohan MK, Choudhury B, Vidyarthi AS, Ghosh P (2009) Nitrilase-catalysed conversion of acrylonitrile by free and immobilized cells of Streptomyces sp. J Biosci 34:21-26

Payne MS, Wu S, Fallon RD, Tudor G (1997) A stereoselective cobalt-containing nitrile hydratase. Biochem 36:5447-5454

Pereira RA, Graham D, Rainey FA, Cowan DA (1998) A novel thermostable nitrile hydratase. Extremophiles 2:347-357

Prasad S, Raj J, Bhalla TC (2009) Purification of a hyperactive nitrile hydratase from resting cells of Rhodococcus rhodochrous PA34. Indian J Microbiol 49:237-242

Přepechalová I, Martínková L, Stolz A, Ovesná M, Bezouška K, Kopecký J, Křen V (2001) Purification and characterization of the enantioselective nitrile hydratase from Rhodococcus equi A4. Appl Microbiol Biotechnol 55:150-156

Raj J, Prasad S, Bhalla TC (2006) Rhodococcus rhodochrous PA34: a potential biocatalyst for acrylamide synthesis. Process Biochem 41:1359-1363

Ray SC, Nandi LN, Singh B, Prasad H, Maharaj S, Sarkar PK, Dutta P, Roy SK, Yadav SN, Bandyopadhyay AK (2004) Process for the synthesis of isonicotinic acid hydrazide.US Patent 6,734,309

Sachi O, Lindsay D (2007) Purification and characterization of a novel nitrile hydratase from Rhodococcus sp. RHA1. Mol Microbiol 65:828-838

Srinivasulu B, Adinarayana K, Ellaiah P (2003) Investigations on neomycin production with immobilized cells of Streptomyces marinensis Nuv-5 in calcium alginate matrix. AAPS PharmSciTech 4:1-6

Sugiura Y, Kuwahara J, Nagasawa T, Yamada H (1987) Nitrile hydratase: the first non-heme iron enzyme with a typical lowspin Fe(III)-active center. J Am Chem Soc 109:5848-5850

Tanaka K, Kimura K (1972) Process for preparing amino acids from hydrocarbons. US Patent 3,655,510

Vejvoda V, Kaplan O, Kubáč D, Křen V, Martinková L (2006) Immobilization of fungal nitrilase and bacterial amidase-two enzymes working in accord. BiocatalBiotrans 24:414-418

Watanabe I, Satoh Y, Enomoto K, Seki S, Sakashita K (1987) Optimal conditions for cultivation of Rhodococcus sp. N-774 and for conversion of acrylonitrile to acrylamide by resting cells. AgricBiolChem 51:3201-3206

Wieser M, Takeuchi K, Wada Y, Yamada H, Nagasawa T (1998) Low-molecular-mass nitrile hydratase from Rhodococcus rhodochrous $\mathrm{J} 1$ : purification, substrate specificity and comparison with the analogous high-molecular-mass enzyme. FEMS Microbiol Lett 169:17-22

Yamada H, Shimizu S, Kobayashi M (2001) Hydratase involved in nitrile conversion: screening, characterization and application. The Chem Record 1:152-161 